\title{
EFL Teachers' Assessment Literacy and Their Reflective Teaching
}

\author{
Hamid Ashraf \\ Department of English, Torbat-e Heydarieh Branch, Islamic Azad University, Torbat-e \\ Heydarieh, Iran, h.ashraf@iautorbat.ac.ir

\section{Samaneh Zolfaghari} \\ Department of English, Torbat-e Heydarieh Branch, Islamic Azad University, Torbat-e \\ Heydarieh, Iran, samaneh.zolfaghari.ac@iautorbat.ac.ir
}

Understanding and employing useful classroom assessments are crucial to increase student achievement (Marzano, 2000). Teachers' assessment literacy is viewed as a key link in the connection between assessment quality and student achievement. Reflective teaching is a movement in teacher education and crucial kind of thought that enables teachers to be aware of their experiences and analyze their own practice (Fatemipour \& Hosseingholikhani, 2014). The purpose of the present study, in the first place, is to shed light on the relationship between Iranian EFL teachers' assessment literacy and their reflective teaching. To this end, $120 \mathrm{EFL}$ teachers were selected randomly to fill out two questionnaires: assessment literacy inventory designed by Zolfaghari and Ashraf (2015), and reflective teaching questionnaire designed by Behzadpour (2007). The result of the study suggested that there is a relationship between EFL teachers' assessment literacy and their reflective teaching. Furthermore, it is observed that teachers' assessment literacy predicts their reflective teaching.

Keywords: assessment literacy, reflective teaching, teachers, EFL, language institutes

\section{INTRODUCTION}

Teaching as an intricate activity necessitates qualified teachers. Teachers are considered as the key features for the success in any educational system. As Campbell (2000) mentions, teacher is one of the prominent features in the process of language teaching and learning. Possibly one of the most imperative aspects of the teaching process is assessment procedures since many studies revealed that the use of assessment to promote learning in the classroom improved student achievements (Earl\& Katz, 2006). Therefore, evaluation of students' progress is considered as a key part of teachers' job (Brumfit \& Johnson, 1979). While it is vital for English teachers to be aware of different methods of assessing students, many of the teachers adhere to traditional methods of testing. Therefore, in recent years, increasing numbers of professional development

Citation: Ashraf, H., \& Zolfaghari, S. (2018). EFL Teachers' Assessment Literacy and Their Reflective Teaching. International Journal of Instruction, 11(1), 425-436. https://doi.org/10.12973/iji.2018.11129a 
programs have dealt with assessment literacy for teachers and/or administrators, and various researchers and organizations have specified the content domains in which teachers need to improve assessment skills.

The literature also shows that reflective practice has been widely researched, starting with John Dewey in 1933, who introduced the notion of reflective thought, illustrated as an active consideration of any idea in the light of the prior knowledge and future goals. Richards and Lockhart (1996) note that a reflective approach to teaching is "one in which teachers and student teachers gather data about teaching, observe their manners, beliefs, theories and teaching practices, and utilize the information achieved as a foundation for critical reflection about teaching"(p.1). It is an approach to teaching and to teacher education which is based on the statement that teachers can improve their understanding of teaching and the quality of their own teaching by reflecting critically on their teaching experiences. A reflective teacher is as one who assesses the origins, principles and consequences of work in classroom. As a result of these focused discussions a teacher is able to better understand practice and be able to take steps to develop practice (Rose, 2007). As Griffiths (2000) clarifies, reflection-in-action occurs when "professionals are faced with a circumstances which they experience as distinctive or containing a constituent of surprise. Rather than applying theory or past experience in a direct way, professionals draw on their repertoire of examples to reframe the situation and find innovative solutions"(p. 542). Reflection-on-action, on the other hand, is according to Schon1987, "teachers' thoughtful concerns and retrospective examination of their act in order to achieve knowledge from experience" (cited in Leitch and Day, 2000).

Despite the existence of some theoretical studies related to both variables, however very little if any empirical research exists on the relationship between reflective teaching and teachers' assessment literacy. To fill the gap, the present study aims to tap into the relationship between reflective teaching and EFL teachers' assessment literacy.

\section{Review of the Related Literature}

\section{Teachers' Assessment Literacy}

The term assessment literacy has emerged to illustrate the familiarity and abilities teachers require to be able to plan for, administer, understand and apply the outcomes of assessments accurately and efficiently (Boyles 2005; Stiggins 1999; Stoynoff and Chapelle, 2005). Assessment literacy has been illustrated as considering the philosophy of perfect assessment (Popham, 2004; Stiggins, 2002). Well-informed teachers in this ground are well positioned to integrate assessment with teaching so that they make use of appropriate techniques of teaching (McMillan, 2000). Study in this field goes on to distinguish teachers' assessment and evaluation performances as mostly incongruent with proposed best practice (Galluzzo, 2005; Mertler, 2004). This outcome extends to pre-service teacher candidates who also have a tendency to make use of unsound assessment and evaluation practices (Bachor \& Baer, 2001; Campbell \& Evans, 2000). It is considered that teacher 
education programs and professional development experiences are estimated to be essential for providing teachers with current knowledge about learning and assessment, particularly the knowledge and skills required to develop assessment tasks that would elicit students' higher-order thinking skills or to assess their development and improvement towards competence (Cizek, 2000).

Studies in different parts of the world have revealed that many teachers are inadequately trained and ill-prepared to develop, administer and interpret the outcomes of different types of assessments (e.g., Bol, Stephenson, O'Connell \& Nunnery, 1998; Wiggins, 1989). Furthermore, teachers' assessment practices were often not well supported their instructional goals and tended to demand a low level of cognitive processing. Numerous teachers were found not to be good judges of the quality of their own assessment tasks (Bol\&Strage, 1996).

\section{Reflective Teaching}

Language teaching investigations in the 1970s can originally be seen as some classroom studies, in which there was a process-product approach toward teaching. That is, the teachers' practical teaching and the learners' achievement were monitored to recognize how much a particular kind of teaching would result in learners' learning. If they were found to be effective, the procedures would be identified as supportive ones which could be adopted by other teachers (Borg, 2006, pp. 5-6).

The beginning of reflective teaching study, focusing on teachers' thought, however, can be traced back to the publication of the report by National Institute of Education in 1975. "The report, then, urged for reflecting on the relationship between thought and action as far as the teachers are concerned" (quoted in Borg, 2006, p. 7). As a result, the researchers began to think on and look for teachers' idea as one of the features affecting their teaching behaviour.

Literature also reveals that reflective teaching has been studied in relation with critical thinking. Some investigators consider that the foundation of reflective teaching and thinking critically originated from critical thinking (Cornford, 2002; Hillier, 2005). Van Manen (1991; cited in El-Dib, 2007, p. 25) describes reflection as "the procedure by which teachers engage in aspects of critical thinking such as careful deliberation and analysis, making choices, and reaching decisions about a course of action associated with teaching".

In a study carried out by Gobena (2016), the attitude of principals, supervisors and mentees concerning action research as reflective practices was investigated. The result of the study showed that there is a relationship between lack of innovative methodologies, lack of instructional materials and lack of dedication from lecturers and attitudes towards action research as reflective practices. As a result, principals and supervisors of the implementing unit of the system should behave morally, practically, professionally, ethically, responsibly and critically so as to accommodate professional requirement of the nation to bring behavioural amendments and quality education for the Ethiopian children. 
In this study, the researchers tried to find out if there is any significant relationship between teachers' assessment literacy and their reflective teaching. Also, they aimed to discover whether teachers' reflective teaching predicts their assessment literacy. Therefore, the following questions were proposed:

\section{Research Questions}

Q1: Is there any significant relationship between EFL teachers' Assessment Literacy and their Reflective Teaching?

Q2: Do components of teachers' Assessment Literacy predict Reflective Teaching?

\section{METHOD}

\section{Participants}

To collect the required data 120 Iranian EFL teachers teaching in different institutes of Mashhad were selected randomly. They were considered experienced teachers having university education (Bachelor or Master or $\mathrm{PhD}$ degree). They were both males and females from different age groups and different years of experiences. Their fields of study were English language teaching, Translation, and English literature.

\section{Materials}

The needed data for this study were gathered through the application of one researcher made questionnaire for assessing EFL teachers' assessment literacy and reflective teaching questionnaire. The 50 item assessment literacy questionnaire designed by Zolfaghari \& Ashraf, (2015) included the following 3 subscales: teachers' disposition about assessment ( 8 items, maximum score 40 ), teachers' knowledge about assessment (14 items, maximum score 70), and teachers' performance (14 items, maximum score 70). Items of the first two sub scales were measured on 5-point scale: "strongly disagree, disagree, neutral, agree, and strongly agree." The items of the last subscale were 40 measured on the following 5 point scales: "never, rarely, sometimes, usually, and always." the reliability was estimated using Cronbach's Alpha .90.

The instrument which was employed for evaluating reflective teaching in this study was the one designed by Behzadpour (2007) and included 42 items in a multiple-choice test format. This was a five-point Likert scale, consisting of five choices ranging from never to always, which has been devised based on six factors; Cognitive, Metacognitive, Affective, Practical, Critical, and Moral. Behzadpour's inventory was chosen for the purpose of this study because it was developed for measuring teachers' reflection in the context of Iran and it enjoys a high reliability of .90 as a measuring instrument for teacher reflectivity (Behzadpour, 2007).

\section{Procedure}

In this study, 120 participants who were all Iranian ELT teachers in different language institutes were selected randomly. For collecting the data, both questionnaires (assessment literacy and reflective teaching) in the form of papers were spread up to different English Language teachers. Collected data were analyzed using SEM. 


\section{Data Analysis}

In order to examine the interrelationships between the selected variables (reflective teaching, and assessment literacy) a structural model was proposed. Also, the Correlation Coefficients among teachers' reflective teaching and subscales of assessment literacy were calculated.

\section{FINDINGS}

To check the normality of data distribution, the Kolmogorov-Smirnov test was employed. Table 1 presents the results of the Kolmogorov-Smirnov test. As it can be seen, the obtained sig value for both variables is higher than .05. Therefore, it can safely be concluded that the data is normally distributed across all the variables.

Table 1

The results of K-S test

\begin{tabular}{lccl}
\hline & & Kolmogorov-Smirnov $^{\mathrm{a}}$ & \\
& Statistic & $\mathrm{df}$ & Sig. \\
\hline reflective teaching & .980 & 120 & .142 \\
assessment literacy & .755 & 120 & .309 \\
\hline
\end{tabular}

Descriptive statistics for reflective teaching and subscales of assessment literacy, in other words, teachers' disposition about assessment, teachers' knowledge about assessment, and teachers' performance, can be seen in Table 2.

Table 2

Descriptive statistics for reflective teaching and subscales of assessment literacy

\begin{tabular}{llllll}
\hline & $\mathrm{N}$ & Minimum & Maximum & Mean & Std. Deviation \\
\hline Reflective Teaching & 120 & 93.00 & 183.00 & 122.37 & 15.517 \\
Teachers' Disposition & 120 & 12.00 & 38.00 & 28.59 & 3.241 \\
Teachers' Knowledge & 120 & 41.00 & 120.00 & 83.00 & 7.514 \\
Teachers' Performance & 120 & 17.00 & 58.00 & 46.00 & 5.410 \\
Total assessment literacy & 120 & 73.00 & 215.00 & 126.33 & 16.790 \\
\hline
\end{tabular}

The possible range of score for the reflective teaching questionnaire is between 42 and 210 , for teachers' disposition about assessment is between 8 and 40, for teachers' knowledge about assessment is between 28 and 140, and for teachers' performance is between 14 and 70. In addition, the possible range of score for the Total assessment literacy questionnaire is between 50 and 250. As it can be seen in Table 1 the mean score of the teachers' report in reflective teaching was 122.37 with standard deviation of 15.517. Moreover, the mean score of the teachers' report in Total assessment literacy was 126.33 with standard deviation of 16.790 .

To assess the research question 1, correlation was run between teachers' assessment literacy and reflective teaching. Results are demonstrated in Table3. 
Table 3

The Correlation Coefficients among teachers' reflective teaching and subscales of assessment literacy

\begin{tabular}{ll} 
& Ref \\
\hline Teachers' Disposition & .110 \\
Teachers' Knowledge & $.487 * *$ \\
Teachers' Performance & $.624 * *$ \\
5. Total Assessment Literacy & $.593 * *$ \\
\hline *Correlation is significant at the levelof 0.05 &
\end{tabular}

As it is demonstrated by the table, there is a positive relationship between teachers' assessment literacy and reflective teaching. In addition, the highest correlation is observed between teachers' reflective teaching and their performance and the lowest correlation was obtained between teachers' reflective teaching and their disposition about assessment. However, there was no significant relationship between reflective teaching and teachers' disposition about assessment was not significant $(r=.110, p=$ 0.116). As table 2 demonstrates.

To assess the Research Question 2, structural equation modeling (SEM) was conducted. As indicated in Figure 1, EFL teachers ' reflective teaching is positive significant predicator of their knowledge about assessment $(\beta=.340, p<0.05)$ and their performance $(\beta=.518, p<0.05)$. However, the path from reflective teaching to teachers' disposition about assessment was not significant $(\beta=.07, p>0.05)$. 


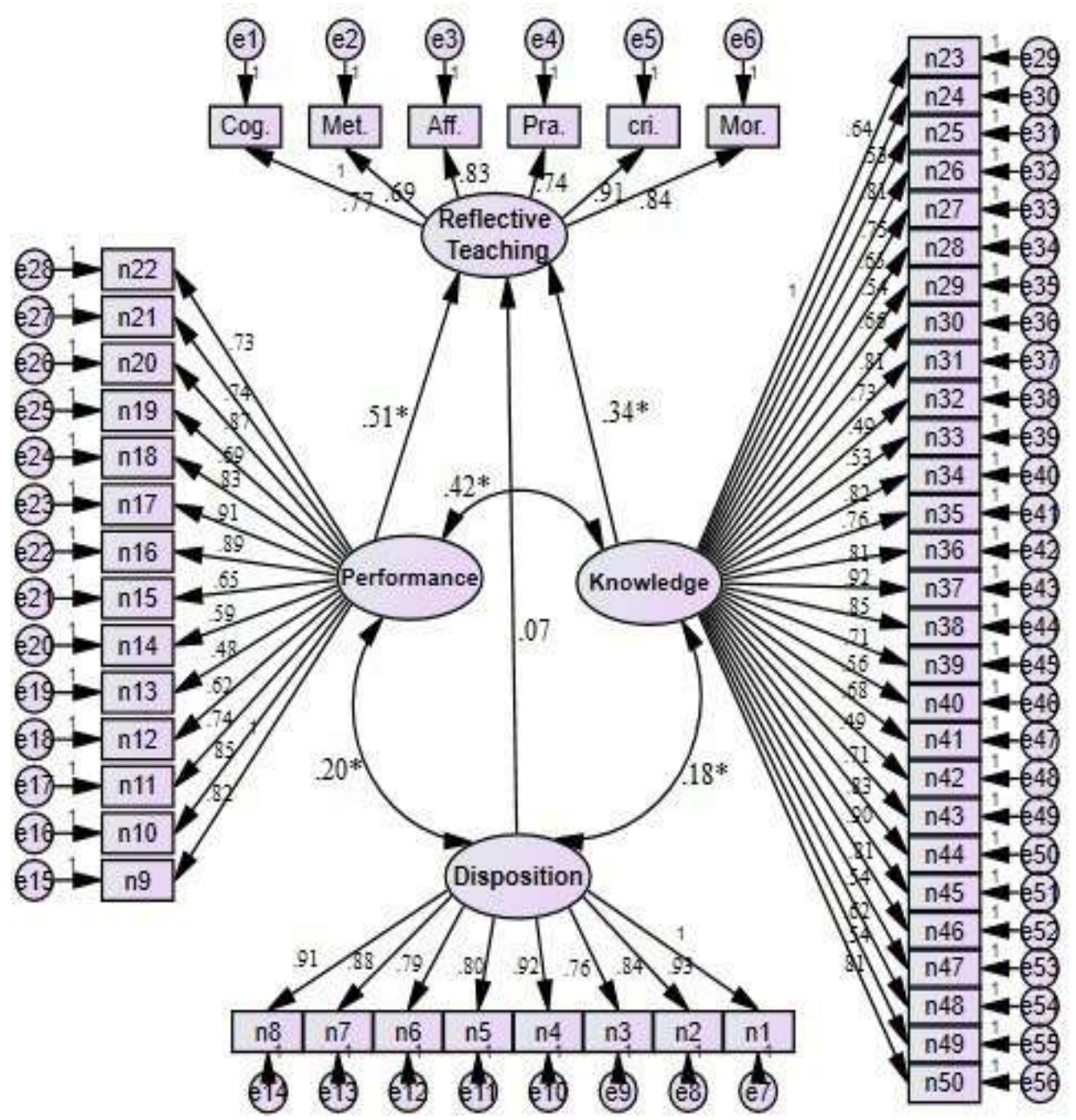

Figure 1

The schematic representation of the relationships among reflective teaching and subscales of assessment literacy

As the results indicated, the chi-square value (8.294), the chi-square/df ratio (2.764), RMSEA (.071), GFI (.901), and CFI (.934), all the fit indices lie within the acceptable fit thresholds. Hence, it can be concluded that the proposed model had perfect fit with the empirical data. (*)marks in the model shows the significance.

\section{DISCUSSION AND CONCLUSION}

There has been substantial discussion in recent years concerning the significance of improving teachers' assessment literacy (Deluca \& Klinger, 2010; Popham, 2009a; 
Volante \& Fazio, 2007). Unfortunately, many teachers were not trained in assessment therefore they know little about assessment (Popham, 2004, 2009a). In fact, "one of the most serious problems in today's education profession is that the level of educators' "assessment literacy" is so abysmally low" (Popham, 2010, p. 175).

Another concept examined in many researches in the field of pre-service literacy teacher education is the need for teacher reflection on the process (Odo, 2015). Research in this area demonstrated the wide variety of forms that reflection can take. Researchers highlight the significance of teacher reflection for improving their understandings of instructional strategies, teaching challenges, and increasing awareness of their own implicit ideas (Brookfield, 1995) as well as the ability to integrate their growing knowledge into a coherent framework (Larrivee, 2000), and improving their assessment literacy (Odo, 2015).

Pollard (2002) notes that reflective teachers will be aware of the complex issues surrounding assessment and pupil progress, as well as the ways in which assessment will support learning.

Considering the importance of assessment literacy and reflective teaching in recent years, the present study sought to explore the relationship between EFL teachers' Assessment Literacy and their Reflective Teaching. The findings of the study revealed that there is a positive correlation between EFL teachers' assessment literacy and their reflective teaching. This implies that the more teachers' assessment literacy, the more their reflection on their teaching. In other words, by increasing teachers' assessment literacy their reflection on their teaching increases too. Besides, among the three subscales of assessment literacy, the highest correlation is observed between teachers' reflective teaching and their performance and the lowest correlation was obtained between teachers' reflective teaching and their disposition about assessment.

Finally, in order to find whether teachers' assessment literacy predicts their reflective teaching structural equation modeling (SEM) was conducted. The proposed model suggests that EFL teachers' Assessment Literacy predicts their Reflective Teaching.

The result of the study were consistent with the findings of Yazdani, Amirian \&Hedayati (2015), which suggests that there is a positive relationship between reflective teaching and EFL teachers' evaluation of students' achievement. The findings also give support for the arguments of Cole (1997), Coyle (2002) who believe that reflective teachers are involved in analyzing, discussing, evaluating, changing, and developing their practice, which will eventuate into student improvement.

The most significant implication is that teacher education programs that offer specific courses on assessment and evaluation and many pre-service programs currently do not assume their teacher candidates are graduating with an adequate level of assessment literacy to assess students effectively (Campbell, Murphey \&Holt, 2002). Consequently, it is necessary for all educational curriculums to provide teachers with adequate knowledge and skills in assessment. 
Teacher educators and professional developers need to form a range of assessment methods within their own coursework and professional development opportunities so that pre-service students and in-service teachers construct a deeper understanding of the utility of different assessment approaches (Davidheiser, 2013).

A worthy of consideration, and further research, is to find out the factors playing role in EFL teachers' illiteracy in assessment related matters. Further research is also required to find the relationship between EFL teachers' assessment literacy and their teaching style. Similarly, since SEM was used in the present study, it is suggested to use other statistical methods to find the relationship between teachers; assessment literacy and reflective teaching.

\section{REFERENCES}

Behzadpour, F. (2007). Developing a measuring instrument for reflective teaching. Unpublished masteral thesis, Tarbiat Modares University, Tehran, Iran.

Bachor, D. G., \& Baer, M. R. (2001). An examination of preservice teachers' simulated classroom assessment practices. Alberta journal of educational research, 47(3), 244.

Bol L., Strage A. (1996). The contradiction between teachers' instructional goals and their assessment practices in high school biology courses. Science Education, 80, 145 163.

Bol, L., Stephenson, P. L., O'connell, A. A., \& Nunnery, J. A. (1998). Influence of experience, grade level, and subject area on teachers' assessment practices. The Journal of Educational Research, 91(6), 323-330.

Boyle-Baise, M. (2005). Preparing community-oriented teachers: Reflections from a multicultural service-learning project. Journal of Teacher Education, 56(5), 446-458.

Brookfield, S. D. (1995). Becoming a critically reflective teacher. San Francisco: Jossey-Bass.

Brumfit, C. J., \& Johnson, K. (1979). The linguistic background. The communicative approach to language teaching, 1-45.

Campbell, C., \& Evans, J. A. (2000). Investigation of preservice teachers' classroom assessment practices during student teaching. The Journal of Educational Research, 93(6), 350-355.

Campbell, C., Murphy, J. A., \& Holt, J. K. (2002). Psychometric analysis of an assessment literacy instrument: Applicability to preservice teachers. In Annual meeting of the mid-western educational research association, Columbus, $\mathrm{OH}$.

Cizek, G. J. (2000). Pockets of resistance in the assessment revolution. Educational Measurement: Issues and Practice, 19(2), 16-23.

Cole, A. L. (1997). Impediments to reflective practice: Toward a new agenda for research on teaching. Teachers and teaching, 3(1), 7-27. 
Cornford, I. R. (2002). Reflective teaching: Empirical research findings and some implications for teacher education. Journal of Vocational education and Training, 54(2), 219-236.

Coyle, D. (2002). The Case for Reflective Model of Teacher Education in Fundamental Principles. Module Ed.D School of Education University of Nottingham.

Davidheiser, S. A. (2013). Identifying areas for high school teacher development: A study of assessment literacy in the Central Bucks School District (Doctoral dissertation), Drexel University).

DeLuca, C., \& Klinger, D. A. (2010). Assessment literacy development: Identifying gaps in teacher candidates' learning. Assessment in Education: Principles, Policy \& Practice, 17(4), 419-438.

Dewey, J. (1933). How we think. A restatement of the relation of reflective thinking to the educative process. Boston: DC Heath and Company.

Earl, L. M., \& Katz, S. (Eds.). (2006). Leading schools in a data-rich world: Harnessing data for school improvement. Corwin Press.

El-Dib, M. A. B. (2007). Levels of reflection in action research. An overview and an assessment tool. Teaching and teacher education, 23(1), 24-35.

Fatemipour, H., \& HosseingholiKhani, F. (2014). The impact of reflective teaching on the efl teachers' performance. Stud, 4(4), 796-799.

Galluzzo, G. R. (2005). Performance assessment and renewing teacher education the possibilities of the NBPTS standards. The Clearing House: A Journal of Educational Strategies, Issues and Ideas, 78(4), 142-145.

Gobena, G. A. (2016). Attitude of school principals, supervisors and mentees towards action research as reflective practices. International Journal of Instruction, 10(1).

Griffiths, V. (2000). The reflective dimension in teacher education. International Journal of Educational Research, 33(5), 539-555.

Hillier, Y. (2005). Reflective teaching in further and adult education. A\&C Black.

Larrivee, B. (2000). Transforming teaching practice: Becoming the critically reflective teacher. Reflective practice, 1(3), 293-307.

Leitch, R., \& Day, C. (2000). Action research and reflective practice: Towards a holistic view. Educational Action Research, 8(1), 179-193.

Marzano, R. J. (2000). Transforming classroom grading. Alexandria, VA: Association for Supervision and Curriculum Development.

McMillan, J. H. (2000). Fundamental assessment principles for teachers and school administrators. Practical Assessment, Research \& Evaluation, 7(8), 1-9. 
Mertler, C. A. (2004). Secondary teachers' assessment literacy: Does classroom experience make a difference?. American Secondary Education, 49-64.

Odo, D. (2015). Improving urban teachers' assessment literacy through synergistic individualized tutoring and self-reflection.Networks: An Online Journal for Teacher Research, 17(2), 1-13.

Pollard, A. (2002). Reflective teaching: Effective and evidence-informed professional practice ([New ed.], Andrew Pollard with contributions by Janet Collins. London, England: Continuum.

Popham, W. J. (2004). Why assessment illiteracy is professional suicide. Educational Leadership, 62(1), 82.

Popham, W. J. (2009a). Assessment literacy for teachers: Faddish or fundamental?. Theory into practice, 48(1), 4-11.

Popham, W. J. (2010). Everything school leaders need to know about assessment. Thousand Oaks: Corwin Press.

Richards, J. C., \& Lockhart, C. (1996). Reflective teaching in second language classrooms. TESOL Journal, 1(2), 7-10.

Rose, M. A. (2007). Perceptions of technological literacy among science, technology, engineering, and mathematics leaders.

Schön, D. A. (1987). Educating the reflective practitioner: Toward a new design for teaching and learning in the professions. Jossey-Bass.

Stiggins, R. J. (1999). Assessment, student confidence, and school success. The Phi Delta Kappan, 81(3), 191-198.

Stiggins, R. J. (2002). Assessment crisis: The absence of assessment for learning. Phi Delta Kappan, 83(10), 758-765.

Stoynoff, S., Chapelle, C. A., \& Viii, P. (2005). ESOL tests and testing. Alexandria, VA: TESOL.

Van Manen, M. (1991). The tact of teaching: The meaning of pedagogical thoughtfulness. suny Press.

Volante, L., \& Fazio, X. (2007). Exploring teacher candidates'assessment literacy: implications for teacher education reform and professional development. Canadian Journal of Education, 30(3), 749.

Wiggins, J. S., \& Pincus, A. L. (1989). Conceptions of personality disorders and dimensions of personality. Psychological Assessment: A Journal of Consulting and Clinical Psychology, 1(4), 305. 
Yazdani, H., Amerian, M., \& Hadadi, A. (2015). The relationship between reflective teaching and efl teachers'evaluation of students'achievement. Modern Journal of Language Teaching Methods, 5(3), 195.

Zolfaghari, S., \& Ashraf, H. (2015). The relationship between EFL teachers' assessment literacy, their teaching experience, and their Age: A case of Iranian EFL teachers. Theory and Practice in Language Studies, 5(12), 2550-2556. 